\title{
Interaction Effect of Season, Habitat and Leaf Age on Proximate Composition of Senna occidentalis and Senna obtusifolia Leaves Grown in Fadama and Upland Locations in Sokoto, Nigeria
}

\author{
${ }^{* 1}$ U. Tambari, ${ }^{2}$ B. L. Aliero, ${ }^{2}$ S. Muhammad and ${ }^{3}$ L.G. Hassan \\ 1Department of Biology, School of Sciences, Shehu Shagari College of Education, Sokoto, Nigeria \\ 2Department of Biological Sciences, Faculty of Science, Usmanu Danfodiyo University, Nigeria \\ 3Department of Pure and Applied Chemistry, Faculty of Science, Usmanu Danfodiyo University, Sokoto, Nigeria \\ [Correspondence Address: utambari@gmail.com; : : +2348053014730]
}

\begin{abstract}
This study was aimed to assess the effect of season, habitat and leaf age on proximate composition of leaves of Senna occidentalis L. and S. obtusifolia L. Leaves samples were collected from stands of Fadama Research Farm and Upland (Biological garden) at Permanent Site, Usmanu Danfodiyo University Sokoto and analyzed for nutrient contents using oven drying, muffle furnace ashing, soxhlet extraction, distillation and ashing, micro Kjeldahl method, and difference (NFE) methods. Data was subjected to ANOVA and LSD at $0.05 \%$ for means separation. The results for interaction effect were all statistically significant $(P<0.05)$ in the leaves of the two Senna species and were influenced variedly by the treatment factors. Specifically, rainy subseason, fadama and upland habitats, young and matured leaves treatments favoured most of the nutrient contents (e.g. moisture, ash, crude fibre and NFE) in the following ranges : Moisture (31.37 - 81.07\%), Ash (3..50- 80.00\%), Crude Fibre $(1.00-12.50 \%)$, Ether Extract (1.07-5.47 \%), Crude Protein $(7.13-18.94 \%)$ and NFE $(60.49-83.66 \%)$. This indicates that season, habitat and leaf age are important factors affecting plant growth and development. The results suggest that the species may be sources of the nutrients studied and could enrich the dietary intake of individuals.
\end{abstract}

Keywords: Interaction effect, Season, Habitat, Leaf age, Proximate composition, Senna.

\section{INTRODUCTION}

Due to increasing population and economic crises in most developing nations, for example in Nigeria, food insecurity has been a serious threat to growth, development and survival (Hassan et al., 2007), hence partly the focus on non- conventional wild plants for supply of nutrients. Bulus et al. (2007) assert that most people are now incorporating the non-conventional (wild) food plants in their diets, to provide not only nutrients but also traditional treatment for various ailments. Tukan et al. (1998) reported that over the last two decades, studies have revealed that wild or semiwild plants are nutritionally important because of higher vitamins, minerals, essential fatty acids and fibre contents. Some of the plants also enhance taste and colour in diets (Bianco et al., 1998). From the study of Smith et al. (1996) on wild and cultivated plants from regions in Burkina Faso and Niger Republics, the edible wild plants were often the highest in mineral contents particularly in zinc. High protein content was also reported in some wild vegetables in Botswana (Flyman and Afolayan, 2007).

Septic weed or Coffee Senna (Senna occidentalis L.) and Senna obtusifolia L. (Sickle-Senna or Sickle-Pod) are parts of the numerous important wild plant species growing in the savanna region of Nigeria functioning as primary producers in the ecosystem. Their leaves, especially when young, are cooked and eaten as vegetables by majority of the rural communities in the zone. The flowers, fruits and seeds are also parts of the food and sometimes used as medicine for human consumption. These species are also used as fodder for animals. In addition, they provide shade and contribute to the supply of nutrients to the soil to increase soil fertility. The roots, stems and leaves are equally subjected to medicinal uses and the dry stalks as fuel wood in addition to provision of habitat to micro fauna and supply of other tangible products to human population. Evans (1982) reported that almost every part of any plant (root, stem, leaf, bark, flower, fruit and seed) is known to have some uses.

Literature search revealed that these species of plants under study have not been domesticated, but grow in the wild as weeds. S. obtusifolia $L$. is among the leafy vegetables that contribute to the rural women economic income in some parts of the study area (Bello et al., 2008). The contributions of the leaves as dietary food vegetables to the populace in the study area has made 
these species under study very popular in the local communities of Sudan savanna, north-western, Nigeria. Hassan et al, (2002) have reported the following values with respect to proximate composition and mineral contents of C. occidentalis leaves: $82.30 \%$ moisture content, $10.00 \%$ ash, $1.70 \%$ crude fibre, $0.80 \%$ crude lipid, $1.74 \%$ crude protein, $3.46 \% \mathrm{NFE}, 0.68 \mathrm{mg} / \mathrm{kg} \mathrm{Ca}$, $0.15 \mathrm{mg} / \mathrm{kg} \mathrm{Fe}, 0.58 \mathrm{mg} / \mathrm{kg} \mathrm{Mg}, 2.25 \mathrm{mg} / \mathrm{kg} \mathrm{K}, 0.25 \mathrm{mg} / \mathrm{kg}$ $P, 0.50 \mathrm{mg} / \mathrm{kg} \mathrm{Na}$ and $0.05 \mathrm{mg} / \mathrm{kg} \mathrm{Zn}$. They further stated that all the fourteen (14) elements known are essential. But the seven (7) determined elements in the study are the most important and the values obtained were within the ranges of their daily allowance and in conformity with findings of other similar plants of similar habitat in Sokoto and Northern Nigeria. Similarly, Umar et al. (2014) reported that interaction between leaf age and habitat had not significantly effect on the concentration of most nutrient elements studied but ash, crude fibre and $\mathrm{K}$ were significantly higher in young, fadama and upland treatments; ether extract was higher in matured, fadama and upland treatments; and Ca was higher in young and matured; and upland treatments. They concluded that leaf age and habitat are two independent factors that had independently and mutually influenced the concentration of some nutrient elements in the leaves of $C$. tora that has essential roles to play in health. The not yet quantified or unscientifically validated contribution of the leaves of these plants as dietary food vegetables to the populace in the study area has made these species very popular in the local communities.

This study was undertaken with a view to suggest scientific reasons for cultivating the species to ensure their sustainability by raising seedlings in both fadama and upland habitats and determine their foliar chemical compositions to reveal their nutritional potentials in the study area for socio-economic development. The study therefore, determined nutrients based on interaction effect of season, habitat and leaf age on the proximate compositions of the leaves of $S$. occidentalis $L$. and $S$. obtusifolia L. grown in fadama and upland locations of Sokoto, Nigeria.

\section{MATERIALS AND METHODS \\ The Study Area}

The study was conducted at the Permanent Site, Usmanu Danfodiyo University, Sokoto (050 10E - $05^{\circ}$ $12^{1} \mathrm{E}, 13^{0} 040 \mathrm{~N}-13^{0} 0640 \mathrm{~N}$ ) at $308 \mathrm{~m}$ above sea level. The climate is distinguishable into rainy season (May - October) and dry season (November - April), with a relatively cool Harmattan period (November February) (NMA, 2009, and SARDA, 2009). The pattern of rainfall distribution ranges from $553.43-628.94 \mathrm{~mm}$ but relative humidity is about $16-55.5 \%$ (NMA, 2009; SARDA, 2009). The average temperature ranges from $16.3^{\circ} \mathrm{C}$ during harmattan season to $44.7^{\circ} \mathrm{C}$ in the hot season (SARDA, 2009, and NMA, 2009). The fadama land of the area is clayey, hydromorphic, most productive, ecologically sensitive, most highly cultivated, both in the wet and dry season. It is low-lying relatively flat area occurring in streamless depression or adjacent to stream or rivers. The upland soils of the area are predominantly sandy (>90\% sand). The surface texture of the soil is fine sand changing in some cases to loamy sand in the subsoil. Colours are usually dark to dark-red in the surface horizons and reddish brown in the subsoils or in the entire profile. The land is therefore very fragile and susceptible to serious soil erosion during both wet and dry season (Noma and Yakubu, 2002; Adeyeye, 2005; Yakubu et al., 2008).

\section{Treatments and Experimental Design}

The treatments for this study were the stands of the study plant species: S. occidentalis and S. obtusifolia including the experimental sites: fadama and upland areas. It also consist of season (early and late: rainy and dry), and leaf-age (young (0-5days), and mature (>5 days). The experiment was laid in a completely randomized block design (CRBD) with repeated measure. Each of the study plant species had three blocks (beds) as replications respectively at each of the experimental sites (Fadama Research Farm and Biological Garden, permanent site of Usmanu Danfodiyo University Sokoto, Nigeria). The design allows for interaction study based on the treatment components of the study as reflected in result tables.

\section{Sample Collection}

Samples of fresh leaves were collected from the study species (S. occidentalis and S. obtusifolia) right from their seedling stage to their full stage of maturity based on days after sowing (DAS) at harmattan, dry and rainy subseasons of the year. Eight (8) innermost plants were sampled from the two (2) inner rows excluding the border line rows of each of the beds, making a total of twenty four (24) plants per 3 beds sampled for each plant species from fadama and upland locations. The leaf sample collection was done by handpicking tender young (0-5 days) and matured ( $>5$ days) green leaves and put in their respective bags for phytochemical analysis according to Evans (982). 


\section{Nigerian Journal of Basic and Applied Science (June, 2015, 23(1): 39-44}

\section{Preparation of Sample}

The samples were separately collected as young and matured leaves according to location/habitat of the plant (i.e. fadama and upland) for each of the plant species and were thoroughly mixed together in the laboratory before oven drying. The procedures adopted were as described by Krishna and Ranjhan (1980); Evans (1982); and Udo and Ogunwale (1986). The dried samples of each group were then pulverized separately using mortar and pestle and sieved in $0.5 \mathrm{~mm}$ size mesh and stored for chemical analysis at each growing subseason.

\section{Chemical Analyses}

Two grammes $(2 \mathrm{~g})$ of the powdered sample were used in the proximate analysis (Udo and Ogunwale, 1986\}. The determination of each parameter was replicated thrice. The parameters determined were moisture (oven drying); ash (Muffle Furnace Ashing); ether-extract (Soxhlet extraction) and crude-fibre (distillation and ashing). The procedures were as described by Thiammaih (1999). Crude-protein was determined by Microkjeldahl Method; and nitrogen-free extract (NFE) was determined by difference as described by Udo and Ogunwale (1986).

\section{Data Analysis}

Data collected from this study were subjected to analysis of variance (ANOVA). Significant $(P<0.05)$ differences were analyzed using the least significant difference (LSD) to separate the means.

\section{RESULTS AND DISCUSSION}

\section{Moisture Contents}

There was significant $(P<0.05)$ difference in the moisture values obtained (Tables 1 and 2) for the interaction effect of growing season, habitat and leaf age with the highest moisture content obtained (81.07 $\%$ ) during rainy sub-season, at upland and matured leaves treatment in $S$. occidentalis than all the other treatments. Similarly, late rainy growing subseason at fadama and matured leaf treatment gave the highest moisture content $(80.50 \%)$ in S. obtusifolia than all the other treatments. The moisture contents $(33.20-81.07$ $\%$ and $31.37-80.50 \%)$ for $S$. occidentalis and $S$. obtusifolia respectively were below those reported by Hassan et al. (2002) in C. occidentalis (82.30\%); and Adegbola (1985) in fresh leaves $(88.00 \%)$ for leafy vegetables. These findings were in agreement with reports of De Leeuw (1979) and Evans (1982) that differences in nutrient composition found in plant species are due to changes caused by some factors e.g. temperature, rainfall, relative humidity, season, time of day, climate, genetic factors and stage of growth of the leaf or plant, plant age, position of leaves in the crown, habitat of the plant and natural differences that exist between plants. This finding of significant $(P<0.05)$ effect on moisture content for interaction in this study was advancement over similar report made by Umar (2007) on interaction effect of season and stage of leaf development on moisture contents of four tree species but no significant effect was observed.

\section{Ash Contents}

The values of ash obtained in S. occidentalis (3.50 $12.47 \%$ ) and in S. obtusifolia (5.13 - 80. 00 \%) (Tables 1 and 2) were lower and higher than those reported by Hassan et al. (2002) in C. occidentalis leaves (10.00 $\%)$; and those of Umar (2007) respectively for interaction effect of season and stage of leaf development in four tree species (5.97 - 13.88\%). Similar finding was reported by Silmary et al. (2004) that nutrient concentration in the soil had more influence than composition of the foliage for the variation in the nutrient concentration of individual plant caused by differences in the plant's habitat or environment.

\section{Crude - Fibre Contents}

The significant $(P<0.05)$ difference observed in the values of crude fibre ((Tables 1 and 2: $1.00-4.07 \%$ and $1.43-12.50 \%$ in the leaves of $S$. occidentalis $L$. and S. obtusifolia L.) for interaction effect, were within the range when compared with those reported by Ross et al. (1985) for most leafy vegetables $(0.70 \%-12.0$ $\%)$. This finding is in agreement with report of De Leeuw (1979) that the nutrients values of plant is individually and collectively affected by various factors such as edaphic, climatic and genetic factors and varies from time to time and location to location. Gent (2002) reported that differences in leaf nutrient concentration due to season often occurred in early rainfall. This finding implies that more of this nutrient content could be obtained from S. obtusifolia than from S. occidentalis during early rainy sub-season from fadama and young leaves of the stands of the study species. 
Tambari et al.: Interaction Effect of Season, Habitat and Leaf Age on Proximate Composition of Senna occidentalis ......

Table 1: Proximate Composition of Senna occidentalis Leaves as Influenced by Season, Habitat and Leaf Age.

\begin{tabular}{|c|c|c|c|c|c|c|}
\hline Treatments & $\begin{array}{c}\text { Moisture } \\
(\%)\end{array}$ & $\begin{array}{l}\text { Ash } \\
(\%)\end{array}$ & $\begin{array}{c}\text { Crude fibre } \\
(\%)\end{array}$ & $\begin{array}{c}\text { Ether Extract } \\
(\%)\end{array}$ & $\begin{array}{c}\text { Crude protein } \\
(\%)\end{array}$ & N FE (\%) \\
\hline Dry Fadama Young & $61.07^{i}$ & $8.03^{d}$ & $2.53^{\mathrm{c}}$ & $3.53^{c}$ & $11.02^{\mathrm{g}}$ & $74.90^{\circ}$ \\
\hline Dry Fadama Matured & $77.83^{\mathrm{d}}$ & $8.43^{d}$ & $2.93^{c}$ & $5.13^{a}$ & $11.68^{h}$ & $71.81^{\mathrm{d}}$ \\
\hline Dry Upland Young & $73.37^{c}$ & $8.03^{d}$ & $2.47^{d}$ & $4.03^{b}$ & $18.28^{a}$ & $67.21 \mathrm{e}$ \\
\hline Dry Upland Matured & 73.479 & $8.00^{\mathrm{d}}$ & $2.50^{\text {cd }}$ & $5.47^{a}$ & $10.11^{j}$ & $73.91^{\mathrm{c}}$ \\
\hline Early Rainy Fadama Young & $55.37 \mathrm{j}$ & $12.47^{a}$ & $4.03^{a}$ & $2.03^{e}$ & $16.50^{\mathrm{c}}$ & $64.97 e$ \\
\hline Early Rainy Fadama Matured & $33.20^{\mathrm{m}}$ & $12.07^{a}$ & $4.07^{a}$ & $2.47^{e}$ & $15.38^{\mathrm{d}}$ & $66.29 \mathrm{e}$ \\
\hline Early Rainy Upland Young & 46.07 & $11.00^{b}$ & $3.50^{b}$ & $2.03^{e}$ & $17.95^{b}$ & $67.72^{\mathrm{e}}$ \\
\hline Early Rainy Upland Matured & $54.37^{\mathrm{k}}$ & $10.13^{c}$ & $3.00^{b}$ & $3.47^{\mathrm{d}}$ & $15.25^{d}$ & $65.62^{\mathrm{e}}$ \\
\hline Late Rainy Fadama Young & $78.50^{\circ}$ & $7.47^{\mathrm{e}}$ & $2.13^{d}$ & $3.03^{d}$ & 14.419 & $74.98^{c}$ \\
\hline Late Rainy Fadama Matured & $80.03^{b}$ & $3.50^{\mathrm{h}}$ & $1.00^{f}$ & $1.07 \mathrm{~g}$ & $10.76^{i}$ & $83.66^{a}$ \\
\hline Late Rainy upland Young & $78.47^{c}$ & $7.00^{\mathrm{e}}$ & $3.03^{b}$ & $2.50^{\mathrm{de}}$ & $13.66^{\mathrm{e}}$ & $60.49^{f}$ \\
\hline Late Rainy Upland Matured & $81.07^{\mathrm{a}}$ & 4.539 & $1.50^{\mathrm{e}}$ & $1.40^{\mathrm{fg}}$ & $11.48^{h}$ & $80.99^{a}$ \\
\hline Harmattan Fadama Young & $77.07 \mathrm{e}$ & $6.07^{f}$ & $1.50^{\mathrm{e}}$ & $2.47^{e}$ & $12.80^{f}$ & $77.35^{\mathrm{b}}$ \\
\hline Harmattan Fadama Matured & $73.37^{g}$ & $8.37^{d}$ & $2.03^{d}$ & $3.40^{\mathrm{d}}$ & 12.219 & $74.13^{c}$ \\
\hline Harmattan Upland Young & $74.47^{f}$ & $7.07 \mathrm{e}$ & $2.00^{d}$ & $2.10^{\mathrm{e}}$ & $12.80^{f}$ & $76.05^{b}$ \\
\hline Harmattan Upland Matured & $72.13^{\mathrm{h}}$ & $10.07^{c}$ & $2.50^{\text {cd }}$ & $3.50^{\text {cd }}$ & 12.219 & $71.72^{\mathrm{a}}$ \\
\hline Standard Error Mean & 0.16 & 0.04 & 0.03 & 6.28 & 0.15 & 0.75 \\
\hline Significant (5\%) & S & S & $S$ & $S$ & $S$ & $S$ \\
\hline
\end{tabular}

Within a treatment group, means in a column with the same letter(s) are not significantly different using least significant difference (LSD) at 5\% level Using SAS (2003). SEM=Standard Error Mean; S=, NS= Non - Significant; NFE: Nitrogen Free Extract.

\section{Ether Extract Contents}

Result of Tables 1 and 2 reported for Ether Extract in the range of values: $1.07-5.47 \%$ and $1.47-5.47 \%$ for the leaves of $S$. occidentalis $L$. and S. obtusifolia L. were lower and others higher than the values reported by Hassan et al. (2002) in C. occidentalis (1.70\%); and in four tree species $(3.27 \%-12.23 \%)$ reported by Umar (2007) for interaction effect of season and stage of leaf development. These findings are in agreement with report of Abel et al. (1987) that browse plants are good sources of lipids especially during the dry season and good enough for survival despite their relatively good protein content, their quality is usually not sufficient for optimum productivity. This finding implies that the matured leaves obtained from fadama habitat during dry sub-season tend to produce more ether extract than the other treatments.

\section{Crude Protein Contents}

Interaction between season, habitat and leaf age significantly $(P<0.05)$ effect the crude protein content in the leaves of the study species (Tables 1 and 2) with the highest content obtained during dry sub-season, upland habitat and young leaf treatments (18.28 \% in S. occidentalis and $18.94 \%$ in S. obtusifolia) than all the other treatments obtained in the study. The values obtained (10.11 - $18.28 \%$ in S. occidentalis and 7.13 18. $94 \%$ in S. obtusifolia: Tables 1 and 2) were within the range and some higher than those reported by Umar (2007) for interaction effect of season and leaf age in four plant species (3.47 \% - $12.88 \%)$. These observations agreed with the report of Crowder and Chhleda (1982) that higher protein content occurs in plants in the early growing season (dry season in this case) when moisture content is also high and fibre and lignin contents were low but good enough for survival.

\section{Nitrogen - Free Extract (NFE) Contents}

Interaction between season, habitat and leaf age had significant $(P<0.05)$ effect on the content of NFE in $S$. occidentalis (Table 1) and S. obtusifolia (Table 2) with the highest values obtained during late rainy subseason, at upland and fadama habitat, in matured leaves treatments $(83.66 \%$ and $80.99 \%)$ than all the other treatments in $S$. occidentalis, while highest content were also observed during the late rainy and harmattan sub-seasons, fadama and upland habitats, young and matured leaves treatments $(80.47 \%, 80.00$ $\%, 78.20 \%, 77.81 \%$ and $77.60 \%$ ) than all the other treatments in S. obtusifolia. But the values obtained $(60.49-83.66 \%$ and $66.03-80.47 \%$ in the leaves of S. occidentalis L. and S. obtusifolia L.) were commensurate with those reported by Umar (2007) in 


\section{Nigerian Journal of Basic and Applied Science (June, 2015, 23(1): 39-44}

interaction effect of season and leaf age of four tree species $(49.89-78.84 \%)$. This observation agreed with report of Silmary et al. (2004) that variation in the nutrient concentration of individual plants may be caused by differences in habitat or environment. Harper (1989) commented that among the reasons for nutrient variations in plants was that the younger leaves were born in more exposed positions and the older (matured) ones were more likely to be shaded by the young for competition for available light, temperature and other climatic factors that influence nutrient concentration and growth.

Table 2: Proximate Composition of Senna obtusifolia Leaves as Influenced by Season, Habitat and Leaf Age

\begin{tabular}{|c|c|c|c|c|c|c|}
\hline Treatments & $\begin{array}{c}\text { Moisture } \\
(\%)\end{array}$ & $\begin{array}{l}\text { Ash } \\
(\%)\end{array}$ & $\begin{array}{c}\text { Crude fibre } \\
(\%)\end{array}$ & $\begin{array}{c}\text { Ether Extract } \\
(\%)\end{array}$ & $\begin{array}{c}\text { Crude protein } \\
(\%)\end{array}$ & N FE $(\%)$ \\
\hline Dry Fadama Young & $79.13^{\text {cd }}$ & $8.00^{f}$ & $2.50^{\mathrm{de}}$ & $2.97^{c}$ & $13.41^{\mathrm{d}}$ & $73.12^{b}$ \\
\hline Dry Fadama Matured & $80.43^{b}$ & $8.47^{f}$ & $2.03^{e}$ & $5.03^{a}$ & $13.33^{d}$ & $71.16^{c}$ \\
\hline Dry Upland Young & $64.10^{i}$ & $9.03^{\mathrm{e}}$ & $2.03^{e}$ & $3.47^{b}$ & $18.94^{a}$ & $66.55^{\mathrm{d}}$ \\
\hline Dry Upland Matured & $79.00^{d}$ & $9.47 \mathrm{e}$ & $1.43 \mathrm{~g}$ & $5.47^{a}$ & $12.74 \mathrm{e}^{\mathrm{e}} \mathrm{e}$ & $71.37^{b c}$ \\
\hline Early Rainy Fadama Young & $60.43^{k}$ & $11.00^{d}$ & $12.50^{\mathrm{a}}$ & $1.47^{f}$ & $15.77^{\circ}$ & $68.10^{d}$ \\
\hline Early Rainy Fadama Matured & $31.37 \mathrm{~m}$ & $9.47 \mathrm{e}$ & $2.97^{d}$ & $3.13^{b}$ & $17.75^{b}$ & $69.19 c$ \\
\hline Early Rainy Upland Young & $61.43^{j}$ & $12.07^{c}$ & $4.03^{b}$ & $2.53^{c}$ & $13.41^{\mathrm{d}}$ & $68.62^{\mathrm{cd}}$ \\
\hline Early Rainy Upland Matured & $38.07^{c}$ & $11.03^{\mathrm{d}}$ & $3.47^{c}$ & $3.03^{b}$ & $11.88 \mathrm{~g}$ & $74.54^{b}$ \\
\hline Late Rainy Fadama Young & $79.50^{c} \mathrm{c}$ & $80.00^{a}$ & $2.50^{\mathrm{de}}$ & $2.50^{\mathrm{cd}}$ & $8.78^{\mathrm{k}}$ & $78.20^{a}$ \\
\hline Late Rainy Fadama Matured & $80.50^{a}$ & $5.13^{i}$ & $1.50^{f}$ & $1.50^{\mathrm{e}}$ & $11.42^{\mathrm{h}}$ & $80.47^{a}$ \\
\hline Late Rainy upland Young & $78.50^{\mathrm{e}}$ & $8.50^{f}$ & $2.50^{\mathrm{de}}$ & $2.43^{d}$ & $10.11^{k}$ & $77.81^{\mathrm{a}}$ \\
\hline Late Rainy Upland Matured & $79.47^{c}$ & $6.07^{\mathrm{h}}$ & $2.00^{\mathrm{e}}$ & $1.50^{\mathrm{e}}$ & $7.13^{\mathrm{i}}$ & $66.03^{d}$ \\
\hline Harmattan Fadama Young & $78.47 \mathrm{e}$ & $65.50^{b}$ & $1.53^{f}$ & $2.13^{d}$ & $10.36 \mathrm{j}$ & $80.00^{a}$ \\
\hline Harmattan Fadama Matured & $74.50 \mathrm{~g}$ & $8.03^{f}$ & $2.07^{e}$ & $3.07^{b}$ & $12.54^{f}$ & $74.98^{b}$ \\
\hline Harmattan Upland Young & $77.23^{f}$ & $7.50 \mathrm{~g}$ & $2.03^{e}$ & $2.50^{\mathrm{cd}}$ & 10.36 & $77.60^{\mathrm{a}}$ \\
\hline Harmattan Upland Matured & $73.23^{h}$ & $9.43^{\mathrm{e}}$ & $2.37^{\mathrm{e}}$ & $3.43^{b}$ & $12.54^{f}$ & $72.23^{b}$ \\
\hline Standard Error Mean & 0.04 & 0.02 & 0.03 & 0.03 & 0.06 & 1.23 \\
\hline Significant (5\%) & S & S & S & S & S & S \\
\hline
\end{tabular}

Within a treatment group, means in a column with the same letter(s) are not significantly different using least significant difference (LSD) at 5\% level Using SAS (2003). SEM=Standard Error Mean; S=, NS= Non - Significant; NFE: Nitrogen Free Extract.

\section{CONCLUSION}

Nutrients contents of the two plants studied were variedly influenced by the treatment factors such as rainy season, fadama and upland habitats, young and matured leaves. Treatments favoured most of the nutrient contents. Similarly, Ether Extract and Crude Protein in the leaves were higher during dry season, at upland location, in young and matured leaves treatments. Furthermore, season, habitat and leaf-age are three important factors affecting plant growth and developments.

\section{Recommendations}

For further study, similar research should be conducted on other similar parameters and species to bring out more of their nutritional potentials and their full utilization by the users.

\section{REFERENCES}

Abel, N., Hunter, M., Chandler, N. and Maka, G. (1987). Cattle Keeping, Ecological Change and Communal
Management in Ngwa Ketse, Addis Ababa, IICA; 200P.

Adegbola, T.A. (1985). Browse Plants; Propagation, Management and Utilization. In: Adu, I.F. Osinowo, B, Taiwo, B.A and W.S. Alhassan (eds); Proceedings of National Conference on Small Ruminants Production In Nigeria, N.AP.R.I. Shika, Zaria, Kaduna. Pp. 95 - 99.

Adeyeye, E.I. (2005). Trace Metals in Soils and Plants from Fadama Farms in Ekiti State, Nigeria. The Bulletin of Chemical Society Ethopia, 19(1): 23 - 34.

Bello, A.G., Isah, A.D. and Umar, T. (2008). Forest and Forest Products for Accelerated Economic Development of Rural Women in Sokoto State Nigeria: Research For Development In Forestry, Forest Products And Natural Resources Management : Onyekwelu, J. C., Adekunle, V. A. J. and Oke, D, O. (eds) Proceedings of the First National Conference of the Forest and Forest Products Society of Nigeria, Federal University of 
Technology, Akure, Nigeria, $16^{\text {th }}-18^{\text {th }}$ April. Pp 104 107.

Bianco, V. V., Santamaria, P. and Elia, A. (1998). Nutritional Value and Nitrate Content in Edible Wild Species used in South Italy, 3rd Proceeding on Diversification of Vegetable Crops, Acta Horticulture, 46(7): $71-87$.

Bulus, T., Atawodi, S.E. and Mamman, M. (2007). Acute Toxicity: Evaluation of Aqueous Extract of Terminatia mollis on Rats": ChemClass Journal, 4: $57-59$.

Crowder, H. L. and Chhleda,H. L. (1982). Tropical Grassland Husbandry. Longman Inc., New York, Pp. 562.

De Leeuw, P. N. (1979). A Review of the Ecology and Fodder Resources of the Sub-Humid Zone, NAPRI Symposium on Livestock Production in Sub-Humid Zone of West Africa, No. 32, Shika, Kaduna State, Nigeria.

Evans, J. (1982). Plantation Forestry in the Tropics, Oxford University Press, New York, Pp. 350.

Flyman, M. V., and A. J. Afolayan (2007). Proximate and Mineral composition of the Leaves of Momordica balsama L.: Under-utilized Wild Vegetable in Bostwana. International Journal of Food Sciences and Nutrition. 58(6): $419-424$.

Gent, M.P.N. (2002). Nutrient Composition of Salad Green as a Function of Season and Fertilization, Plant Nutrition, 25: 981- 998.

Harper, L. (1989). Canopies as Population. In: Russel, G.; Marshall, B., and P. G. Jarvis (eds): Plant Canopies: Their Growth, Form and Function, 1 st Published. Cambridge University Press, Great Britain: Pp 105 128.

Hassan, L.G., Sani, N.A. and. Faruk, U.Z. (2002). Nutrient Composition of Cassia occidentalis (L) Leaves, Journal of Agriculture and Environment, 3(2): 399 403.

Hassan, L.G., Umar, K.J. and Tijjani, A.A. (2007). Preliminary Investigation on the Feed Quality of Monechma cilliton Seeds. ChemClass Journal, 4: 74 $-83$.

Krishna, G. and Ranjhan, S.K. (1980). Laboratory Manual for Nutrition Research. New Delhi, India: Vikas Publising House Pvt Ltd. Pp.14 - 84.

Nigerian Meteorological Agency - NMA, (2009). 2009 Meteorological Data Report: Sultan Abubakar III International Airport Sokoto, Pp. 1 - 2.

Noma, S. S. and M. Yakubu (2002). Properties and Classification of Soils in the Main Campus of Usmanu Danfodiyo University, Sokoto, Nigeria. Journal of Agriculture and Environment, 3(1): 156 166.
Ross, J. K., English, C. and Perlimutter, C. A. (1985). Dietary Fibre of Selected Fruits and Vegetables. Journal of American Dieticians Association, 7: 1111 $-1116$

Sokoto Agricultural and Rural Development Authority SARDA (2009). 2009 Meteorological Data Report: Pp. 1 - 3.

Silmary, J. G. A., Rosane, G. C. and Fernandes, G. W. (2004). Effects of Genetic Variability and Habitat of Qualea parviflora (Vochysiaceac) on Herbivory by Free - Feeding and Gall-Forming Insects: Accessed on $\quad 9 / 10 / 2010$ from http://www.aob.oxfordjournals.org/cont/full/94/2/259.

Smith, G. C., Cligg. M. S., Keen, K. L. and Grivetti, L.E. (1996). "Mineral Values of Selected Plants Food Common to Southern Burkina Faso and to Niamey, Niger, West Africa": International Journal of food Sciences and Nutrition. 47: 41 - 53.

Thiammaiah, S. K. (1999).Standard Methods of Biochemical Analysis. Kilani Publisher, New Delhi, India. Pp. 1032 - 1044.

Tukan, S. K., Takuri, H. R. and Al-Eisaw, D. M. (1998). "The Use of Wild Edible Plants in the Jordanian Diet": International Journal of Food Sciences and Nutrition. 49: 225 - 235.

Udo, E. J. and Ogunwale, J. A. (1986). Laboratory Manual for the Analysis of Soil, Plants and Water Samples. $2^{\text {nd }}$ Edition. London: Macmillan Publisher. Pp. 67 137.

Umar, T., Shinkafi, M.A. and A.B. Gwaram (2005). "Effects of Leaf Age on Mineral Elements

Concentration in Baobab (Adansonia digitata Linn)": Bulletin of Science Association of Nigeria, 41 4 st Annual Conference Proceedings, Usmanu Danfodiyo University Sokoto. 26: 265 - 269.

Umar, T. (2007). Nutrient Levels in the Leaves of Four Indigenous Trees in Sudan Savanna of North Western, Nigeria. An M.Sc. Dissertation Submitted to the Department of Forestry and Fisheries, U.D.U.S. (Unpublished). Pp. 121

Umar, T., Abdullahi, A. A. and Malami, U. M. (2014). Effect of Leaf Age and Habitat on Nutrient Contents of Cassia tora Linn. In Sudan Savanna Ecosystem of Nigeria. A Research Project Report Submitted to ETF Research Grants Committee, Shehu Shagari College of Education Sokoto, Nigeria. Pp. 111.

Yakubu, M., Abdoulaye, O., Dikko, A. U. and Noma, S. S. (2008). "Soils and Nutrients Losses and Gains during the Rainy Season in the Fadama of Semi Arid Sokoto, Nigeria: Nigerian Journal of Basic and Applied Sciences, 16(2): 202 - 212. 